\title{
Languages from the World of the Bible
}





\title{
Languages from the World of the Bible
}

\author{
edited by \\ Holger Gzella
}

De Gruyter 


\section{(cc) BY-NC-ND}

This work is licensed under the Creative Commons Attribution-NonCommercial-NoDerivs 3.0 License, as of February 23, 2017. For details go to http://creativecommons.org/licenses/by-nc-nd/3.0/.

ISBN 978-1-934078-61-7

e-ISBN 978-1-934078-63-1

\section{Library of Congress Cataloging-in-Publication Data}

Languages from the world of the Bible / edited by Holger Gzella.

$$
\text { p. cm. }
$$

Includes bibliographical references and index.

ISBN 978-1-934078-61-7 (alk. paper)

1. Middle Eastern philology. 2. Semitic philology. 3. Middle East-Languages-

Grammar, Comparative. 4. Middle Eastern literature-Relation to the Old

Testament. 5. Middle Eastern literature-Relation to the New Testament. 6. Bible.

O.T.-Criticism, interpretation, etc. 7. Bible. N.T. - Criticism, interpretation, etc.

I. Gzella, Holger, 1974-

PJ25L36 2011

$492-$ dc23 2011038199

Bibliographic information published by the Deutsche Nationalbibliothek

The Deutsche Nationalbibliothek lists this publication in the Deutsche

Nationalbibliografie; detailed bibliographic data are available in the Internet at http://

dnb.d-nb.de.

(C) 2012 Walter de Gruyter, Inc., Boston/Berlin

(C) Original edition „Sprachen aus der Welt des Alten Testaments“ 2009 by WBG

(Wissenschaftliche Buchgesellschaft), Darmstadt

Cover image: Erich Lessing/Art Resource, NY

Typesetting: Apex CoVantage, LLC, Madison, Wisconsin, USA

Printing: Hubert \& Co. GmbH \& Co. KG, Göttingen

( Printed on acid-free paper

Printed in Germany

www.degruyter.com 